\title{
Chemometric Analysis of Proteolysis During Ripening of Ragusano Cheese*
}

\author{
V. Fallico, ${ }^{1}$ P. L. H. McSweeney, ${ }^{2}$ K. J. Siebert, ${ }^{3}$ \\ J. Horne, ${ }^{1}$ S. Carpino, ${ }^{1}$ and G. Licitra ${ }^{1,4}$ \\ ${ }^{1}$ CoRFiLaC, \\ Regione Siciliana, 97100 Ragusa, Italy \\ 2Department of Food and Nutritional Sciences, \\ University College, Cork, Ireland \\ ${ }^{3}$ Department of Food Science and Technology, \\ Cornell University, Geneva, New York 14456 \\ ${ }^{4}$ Dipartimento di Scienze Agronomiche, \\ Agrochimiche e delle Produzioni Animali, \\ Catania University, Via Valdisavoia 5, Italy
}

\begin{abstract}
Chemometric modeling of peptide and free amino acid data was used to study proteolysis in Protected Denomination of Origin Ragusano cheese. Twelve cheeses ripened 3 to 7 mo were selected from local farmers and were analyzed in 4 layers: rind, external, middle, and internal. Proteolysis was significantly affected by cheese layer and age. Significant increases in nitrogen soluble in $\mathrm{pH} 4.6$ acetate buffer and $12 \%$ trichloroacetic acid were found from rind to core and throughout ripening. Patterns of proteolysis by urea-PAGE showed that rind-to-core and age-related gradients of moisture and salt contents influenced coagulant and plasmin activities, as reflected in varying rates of hydrolysis of the caseins. Analysis of significant intercorrelations among chemical parameters revealed that moisture, more than salt content, had the largest single influence on rates of proteolysis. Lower levels of $70 \%$ ethanol-insoluble peptides coupled to higher levels of 70\% ethanol-soluble peptides were found by reversed phase-HPLC in the innermost cheese layers and as the cheeses aged. Nonsignificant increases of individual free amino acids were found with cheese age and layer. Total free amino acids ranged from $14.3 \mathrm{mg} / \mathrm{g}(6.2 \%$ of total protein) at $3 \mathrm{mo}$ to $22.0 \mathrm{mg} / \mathrm{g}$ (8.4\% of total protein) after $7 \mathrm{mo}$. Glutamic acid had the largest concentration in all samples at each time and, jointly with lysine and leucine, accounted for $48 \%$ of total free amino acids. Principal components analysis and hierarchical cluster analysis of the data
\end{abstract}

Received March 17, 2004.

Accepted May 15, 2004.

Corresponding author: V. Fallico; e-mail: enzofallico@corfilac.it.

*Use of names, names of ingredients, and identification of specific models of equipment is for scientific clarity and does not constitute any endorsement of the product by the authors, CoRFiLac, University College Cork, Cornell University, and Catania University. from reversed phase-HPLC chromatograms and free amino acids analysis showed that the peptide profiles were more useful in differentiating Ragusano cheese by age and farm origin than the amino acid data. Combining free amino acid and peptide data resulted in the best partial least squares regression model $\left(R^{2}=0.976\right.$; $\mathrm{Q}^{2}=0.952$ ) predicting cheese age, even though the peptide data alone led to a similarly precise prediction $\left(\mathrm{R}^{2}=\right.$ $\left.0.961 ; \mathrm{Q}^{2}=0.923\right)$. The most important predictors of age were soluble and insoluble peptides with medium hydrophobicity. The combined peptide data set also resulted in a $100 \%$ correct classification by partial least squares discriminant analysis of cheeses according to age and farm origin. Hydrophobic peptides were again discriminatory for distinguishing among sample classes in both cases.

(Key words: Ragusano cheese, peptide, free amino acid, chemometrics)

Abbreviation key: FAA = free AA, FDM = fat in DM, HCA = hierarchical cluster analysis, IP $=70 \%$ ethanolinsoluble peptides, PCA = principal component analysis, $\mathbf{P D O}=$ Protected Denomination of Origin, pH4.6SN $=\mathrm{pH} 4.6$ acetate buffer-soluble nitrogen, PLSDA = partial least squares discriminant analysis, PLSR = partial least square regression, RP-HPLC = reversed-phase HPLC, $\mathbf{S} / \mathbf{M}=$ salt in moisture, $\mathbf{S P}=$ $70 \%$ ethanol-soluble peptides, $\mathbf{T C A S N}=12 \%$ TCA-soluble nitrogen, VIP = variable influence on the projection.

\section{INTRODUCTION}

The quality and unique character of some local cheeses with distinctive flavor attributes are closely related to the environmental conditions of milk production, to the type of milk employed, and to the particular technology applied (Urbach, 1990). Pasture feeding is known to contribute to the aroma compounds found in 
milk and cheese made therefrom by providing volatile compounds or their precursors that the animal can transfer to milk via the rumen. Raw milk cheeses generally have more heterogeneous microflora than cheeses made from pasteurized milk, and the use of raw milk is often positively related to increased proteolysis and flavor development (Grappin and Beuvier, 1997). Many of these peculiar features are present in Ragusano cheese, a traditional dairy product of the Hyblean area of Sicily, Italy. It belongs to Caciocavallo cheese family, one of the major pasta filata cheese families together with Mozzarella and Provolone. Typical dairy products of southern Italy, pasta filata cheeses are made according to a unique manufacturing process. The distinctive trait of this technology is the stretching step, during which the acidified curd is cut into long layers and then kneaded in hot water to give various final shapes (Battistotti and Corradini, 1993). Ragusano cheese is a regulated Protected Denomination of Origin (PDO) cheese (Gazzetta Ufficiale Comunità Europea, 1996), produced according to a traditional cheese-making technology (Licitra et al., 1998). Local forage, often pastures, is utilized for feeding cows, and the raw milk is coagulated with rennet paste, using wooden cheesemaking equipment and without adding any starter cultures.

Such biodiversity is considered a distinctive feature of traditional cheeses by both the producers and the consumers. The PDO mark should represent a guarantee for the consumers that cheeses were produced according to local milk production regulations and traditional cheese-making techniques and cheese ripening processes (Innocente, 1997). There is, therefore, an increasing need to establish methods for defining and controlling the qualitative characteristics of typical cheeses in order to secure the consumers choices and to protect traditional products against cheaper industrial imitations (Bütikofer and Fuchs, 1997). The breakdown of the casein matrix during cheese ripening is considered essential for texture and flavor development in most cheese varieties, especially in hard- and semihard-type cheeses (Fox et al., 1993). Characterization of proteolysis is usually performed using electrophoretic and chromatographic techniques, resulting in proteolytic profiles of increasing resolution. Because of the complexity of proteolytic patterns during cheese ripening, chemometrics has been proposed recently as an objective approach for the evaluation of proteolytic profiles and data interpretation. Multivariate analysis of chromatographic or electrophoretic data has been shown to represent a powerful method for discrimination between cheese varieties, cheese quality or for judging cheese maturation (Noël et al., 1998; Pripp et al., 2000; Sousa et al., 2001). Chemometric characterization of some typical Italian hard cooked cheeses, such as Parmigiano Reggiano (Resmini et al., 1985) and Grana Padano (Resmini et al., 1993), has also been performed successfully on the basis of free AA (FAA) data.

While characterization of primary proteolysis in Ragusano cheese has recently been reported (Fallico et al., 2003a), studies on secondary proteolysis and chemometric modeling of proteolytic profiles are not available. The aim of this study was to evaluate proteolysis in PDO Ragusano cheese during ripening by the application of chemometric analysis to peptide and FAA data.

\section{MATERIALS AND METHODS}

\section{Cheese Sampling}

Twelve PDO Ragusano cheeses were supplied by different farmers located in the province of Ragusa. Nine cheeses were from one farm; 3 others were each from different farms. Three random replicates were taken for each ripening period $(3,4,6$, and $7 \mathrm{mo})$ at which Ragusano cheese is tested to obtain the PDO mark. Cheeses were analyzed in 4 layers: rind $(R)$, external (E), middle (M), and internal (I). The sampling pattern used was previously reported by Licitra et al. (2000). Cheese samples analyzed in this study were identified using an abbreviation (e.g., 3R) reporting cheese age (months) and layer.

\section{Compositional Analysis}

Grated cheese samples were analyzed in duplicate. Cheese analyses were as follows: total $\mathrm{N}$ by the Kjeldahl method (IDF, 1993), fat by the Gerber method (IDF, 1997) and $\mathrm{NaCl}$ by the Volhard method (AOAC, 2000). Total solids were determined using a forced-air oven drying method at $100^{\circ} \mathrm{C}$ for $24 \mathrm{~h}$ (AOAC, 2000), while $\mathrm{N}$ soluble in $\mathrm{pH} 4.6$ acetate buffer (pH4.6SN) and $12 \%$ TCA-soluble N (TCASN) were determined (Bynum and Barbano, 1985) and expressed as a percentage of the total $\mathrm{N}$ content.

\section{Assessment of Proteolysis}

Cheese $\mathrm{N}$ fractions soluble and insoluble in $\mathrm{pH} 4.6$ acetate buffer were prepared according to the method of Kuchroo and Fox (1982) with some modifications. A mixture of grated cheese and water $(1: 2, \mathrm{wt} / \mathrm{wt})$ was homogenized using a stomacher at $20^{\circ} \mathrm{C}$ for $10 \mathrm{~min}$. The homogenate was adjusted to $\mathrm{pH} 4.6$ using $0.1 \mathrm{M}$ $\mathrm{HCl}$ and then heated to $40^{\circ} \mathrm{C}$ for $1 \mathrm{~h}$. The suspension was centrifuged at $2460 \times \mathrm{g}$ for $30 \mathrm{~min}$ at $4^{\circ} \mathrm{C}$, and the supernatant was filtered through Whatman No.113 filter paper and glass wool. Aliquots of filtrate (pH4.6SN) were stored at $-20^{\circ} \mathrm{C}$ until used for analysis 
of FAA. Seventy percent ethanol-soluble and -insoluble cheese fractions were prepared from $\mathrm{pH} 4.6 \mathrm{SN}$ according to Kuchroo and Fox (1982) and freeze dried until analyzed by reversed phase-HPLC (RP-HPLC).

The $\mathrm{pH} 4$.6-insoluble $\mathrm{N}$ of the cheeses was analyzed by urea-PAGE using a Protean IIxi vertical slab gel unit (Bio-Rad Laboratories Ltd., Watford, UK) according to the method of Andrews (1983). The gels were stained using a modification of the method of Blakesley and Boezi (1977) with Coomassie brilliant blue G250. Freeze-dried aliquots of the $70 \%$ ethanol-soluble and insoluble cheese extracts were analyzed by RP-HPLC as described by Lynch et al. (1996). Individual FAA were analyzed in the $\mathrm{pH} 4.6 \mathrm{SN}$ fraction of the cheeses as described by Fenelon et al. (2000).

\section{Statistical Analyses}

Chemical parameters were weighted by layer using the factors reported by Licitra et al. (2000). Age-independent effects of cheese layer on these weighted chemical parameters were examined by one-way ANCOVA (layer as a weighted fixed factor, ripening time as a covariate). When significant main effects were found ( $P$ $\leq 0.05$ ), specific mean differences were determined using Tukey's honestly significant difference (HSD) test. This model was chosen largely because ripening time covaried with moisture and salt in moisture $(\mathbf{S} / \mathbf{M})$ in directions that ran counter to expected relationships between these variables and proteolysis measures (e.g., $\mathrm{pH} 4.6 \mathrm{SN}$ ). Relationships between the chemical parameters were examined by correlations among the ageadjusted residuals. Analyses were performed using procedures GLM, REG, and CORR in SAS v.8.2 (SAS Institute, Cary, NC).

Three separate data sets were assembled for data from the $70 \%$ ethanol-soluble peptides (SP), 70\% ethanol-insoluble peptides (IP) and amino acids for the corresponding cheeses. Samples for one 6-mo old cheese had some technical problems during chromatographic analysis and were therefore not included in the statistical analysis. Data from RP-HPLC chromatograms of the SP and IP were obtained by visually recognizing similar peaks in the profiles and using the peak heights units $(\mu \mathrm{Au})$ as variables for statistical analysis (Pripp et al., 2000). The peak heights were found by converting the chromatograms to ASCII files. Concentrations of individual FAA were expressed as micromoles per gram of cheese and used as variables for statistical analysis. Cheese age and farm origin were modeled using the following chemometric techniques. Principal components analysis (PCA) was performed standardizing the variables (mean $=0 ; \mathrm{SD}=1)$. Hierarchical cluster analysis (HCA) was performed using squared Euclidean dis- tances and centroid linkage without standardizing the variables. Exploratory data analyses (PCA and HCA) were performed using Minitab for Windows 98 v.13 (Minitab Inc., State College, PA). Partial least squares regression (PLSR) (Wold et al., 2001) was carried out to model cheese age as a function of the measurements using the SIMCA-S v.6.01 program (Umetrics Inc., Kinnelon, NJ). Models were constructed from each of 7 data sets (FAA, SP, IP, the 32 -way combinations and all 3 combined). Probability plots of the residuals were examined to screen for outliers; in the cases in which these were found, the corresponding samples were removed from the data set, and the analysis was repeated. Partial least squares discriminant analysis (PLSDA) (Barker and Rayens, 2003) was carried out separately on each of the 7 data sets to attempt to classify the samples according to cheese age and farm origin using the SIMCA-S program. The optimal number of PLS components was selected for PLSR and PLSDA solutions using cross-validation (Wold, 1978).

\section{RESULTS AND DISCUSSION}

\section{Chemical Composition}

Age-adjusted means, weighted by layer, and mean differences for the chemical parameters as functions of cheese layer are shown in Table 1. Percentage moisture and salt, $\mathrm{pH}$, ammonia, and the proportion of total $\mathrm{N}$ soluble at pH 4.6 and soluble in $12 \%$ TCA (TCASN) all increased significantly from rind to core $\left(\mathrm{F}_{3,43}>2.8\right)$. Percents protein and $\mathrm{S} / \mathrm{M}$ both decreased significantly across the same layers $\left(\mathrm{F}_{3,43}>3.4\right)$. The inner 2 layers were not significantly different from one another among any of these measures, but both were different from the rind among 5 of the 8 parameters where significant differences were found. The rind and external layers on the other hand had significantly different moisture, salt, and protein contents. This decreasing rate of change as one moved closer to the core suggests a possible curvilinear relationship between the chemical parameters and distance from the rind. Nonsignificant increasing trends were observed from the rind to the core for the proportion of $\mathrm{pH} 4.6 \mathrm{SN}$ soluble in $12 \%$ TCA (TCASN/pH4.6SN) and for total FAA. In both cases. the largest mean difference was between the rind and external layers, lending additional support to the curvilinearity hypothesis identified above.

Eight of the 11 chemical parameters had significant linear relationships with ripening time. Percentage moisture and protein both decreased significantly with increasing ripening time $\left(\mathrm{F}_{1,43}>65.2\right)$, while percents salt, S/M, and all of the proteolysis measures except TCASN/pH4.6SN increased significantly with increasing ripening time $\left(\mathrm{F}_{1,43}>7.9\right)$. The presence of these 
Table 1. Age-adjusted weighted means for the effects of cross-section (rind, external, middle, and internal) on chemical composition of Ragusano cheese. ${ }^{1}$

\begin{tabular}{|c|c|c|c|c|}
\hline & Rind & External & Middle & Internal \\
\hline $\mathrm{pH}$ & $5.22^{\mathrm{a}}$ & $5.29^{\mathrm{ab}}$ & $5.32^{\mathrm{ab}}$ & $5.35^{\mathrm{b}}$ \\
\hline Moisture, \% & $24.48^{\mathrm{a}}$ & $35.85^{\mathrm{b}}$ & $39.67^{\mathrm{c}}$ & $41.23^{\mathrm{c}}$ \\
\hline Salt, $\%$ & $1.81^{\mathrm{a}}$ & $2.40^{\mathrm{b}}$ & $2.57^{\mathrm{b}}$ & $2.51^{\mathrm{b}}$ \\
\hline Protein, \% & $35.03^{\mathrm{a}}$ & $28.92^{\mathrm{b}}$ & $26.88^{\mathrm{c}}$ & $26.54^{\mathrm{c}}$ \\
\hline FDM, \% & 47.51 & 48.07 & 46.15 & 46.85 \\
\hline $\mathrm{S} / \mathrm{M}, \%$ & $7.59^{\mathrm{a}}$ & $6.86^{\mathrm{ab}}$ & $6.61^{\mathrm{ab}}$ & $6.20^{\mathrm{b}}$ \\
\hline $\mathrm{pH} 4.6 \mathrm{SN} / \mathrm{TN}, \%$ & $7.51^{\mathrm{a}}$ & $13.20^{\mathrm{ab}}$ & $16.08^{\mathrm{b}}$ & $16.59^{\mathrm{b}}$ \\
\hline TCASN/TN, \% & $6.08^{\mathrm{a}}$ & $11.15^{\mathrm{ab}}$ & $13.18^{\mathrm{b}}$ & $13.93^{\mathrm{b}}$ \\
\hline TCASN/pH4.6SN, $\%$ & 80.80 & 83.94 & 82.26 & 85.00 \\
\hline Total free amino acids, $\mathrm{mg} / \mathrm{g}$ & 14.30 & 20.50 & 21.86 & 22.02 \\
\hline Ammonia, mg/g & $0.36^{\mathrm{a}}$ & $0.55^{\mathrm{ab}}$ & $0.58^{\mathrm{ab}}$ & $0.62^{\mathrm{b}}$ \\
\hline
\end{tabular}

a,b,c Means sharing common superscripts were not significantly different $(P<0.05)$.

${ }^{1}$ Protein $=$ total nitrogen $\times 6.38 \mathrm{FDM}=$ fat in dry matter. $\mathrm{S} / \mathrm{M}=(($ sodium chloride $) /($ moisture content $)) \times$ 100. $\mathrm{pH} 4.6 \mathrm{SN} / \mathrm{TN}=\mathrm{pH} 4.6$ acetate buffer-soluble nitrogen as a percentage of total nitrogen. $\mathrm{TCASN} / \mathrm{TN}=$ $12 \%$ TCA-soluble nitrogen as a percentage of total nitrogen. TCASN $/ \mathrm{pH} 4.6 \mathrm{SN}=12 \% \mathrm{TCA}$-soluble nitrogen as a percentage of $\mathrm{pH} 4.6$ acetate buffer-soluble nitrogen.

strong linear relationships between ripening time and proteolysis suggests that ripening time by itself has a powerful influence on proteolysis. As Ragusano cheeses were aged, proteolysis continued at least through $7 \mathrm{mo}$ even in the presence of relatively low moisture and high $\mathrm{S} / \mathrm{M}$ contents.

Significant correlations $(P<0.05)$ among the ageadjusted residuals of the chemical measurements are shown in Table 2. Moisture and $\mathrm{pH}$ were positively associated with most of the measures of proteolysis (pH4.6SN, TCASN, FAA, and ammonia) and negatively associated with total protein. Salt in moisture, in contrast, showed inverse correlations with the same measures. It was positively associated with total protein and negatively associated with the measures of proteolysis, although the association with FAA was not significant $(R=-0.25)$. Nearly all of the proteolytic measures were strongly and positively correlated with one another and negatively associated with total protein. The only exceptions were the absence of relationships between $\mathrm{pH} 4.6 \mathrm{SN}$ and TCASN/pH4.6SN $(\mathrm{R}=+0.13)$ or between total protein and TCASN/pH4.6SN $(\mathrm{R}=-0.28)$. Both of these relationships, however, were in the expected directions, and the latter was nearly significant $(P=0.056)$.

Salt on a total weight basis was positively correlated with moisture, $\mathrm{pH}$, and most of the proteolytic measures; salt was also negatively correlated with total protein. While these results were in agreement with the finding of significantly lower salt contents in the rinds compared with other cheese layers (Table 1), they ran decidedly counter to expectations. Guinee and Fox (1984), however, working with Romano-type cheeses, reported nearly identical results. After $122 \mathrm{~d}$ of ripening, these researchers found the lowest salt concentrations in the outer layers, while the highest salt concen-

Table 2. Correlation matrix among age-adjusted residuals of chemical parameters in Protected Denomination of Origin (PDO) Ragusano cheese. ${ }^{1}$

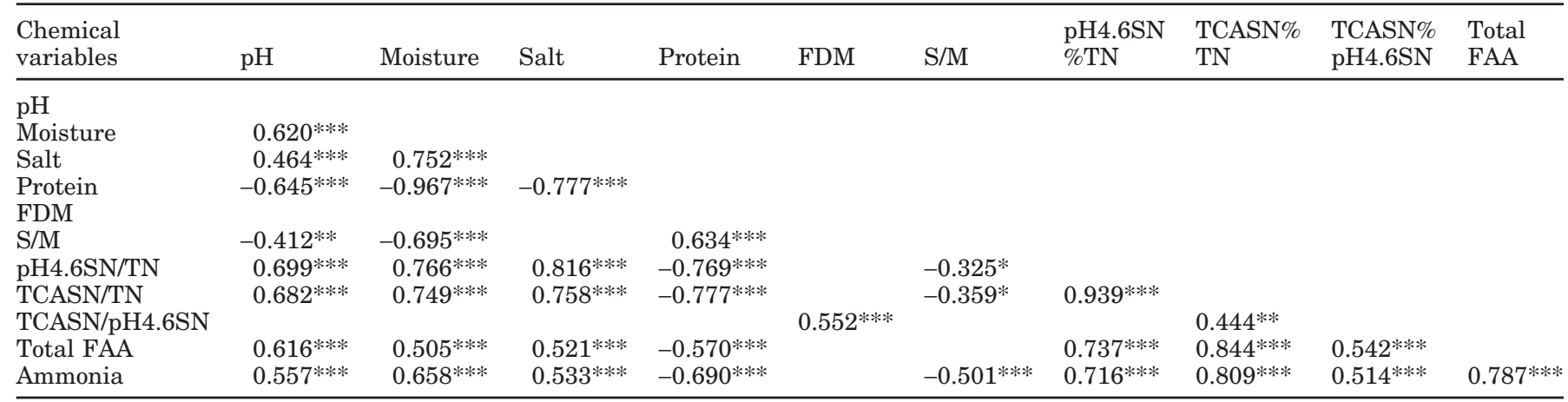

${ }^{1}$ Pearson correlation coefficients at two-tailed significance levels of $* P<0.05 ; * * P<0.01 ; * * * P<0.001$. Protein $=$ total nitrogen $\times 6.38$ $\mathrm{FDM}=$ fat in dry matter. $\mathrm{S} / \mathrm{M}=(($ sodium chloride $) /($ moisture content $)) \times 100 . \mathrm{pH} 4.6 \mathrm{SN} / \mathrm{TN}=\mathrm{pH} 4.6$ acetate buffer-soluble nitrogen as a percentage of total nitrogen. TCASN/TN $=12 \%$ TCA-soluble nitrogen as a percentage of total nitrogen. TCASN $/ \mathrm{pH} 4.6 \mathrm{SN}=12 \% \mathrm{TCA}$-soluble nitrogen as a percentage of $\mathrm{pH} 4.6$ acetate buffer-soluble nitrogen. Total FAA = total free amino acids. 
trations were in the middle layers. They attributed these results to the much faster rate of moisture loss in the outer layer relative to the rest of the cheese. In an effort to maintain osmotic pressure and equilibrium, this rapid rate of moisture loss also caused a decrease in salt on a total weight basis relative to the rest of the cheese. Salt in moisture contents decreased from the rind to the core just as they did in the present study. Our results show that the same process might occur in Ragusano cheese.

Among the chemical parameters, moisture appeared to have the largest single influence on the rate of proteolysis. Rind-to-core moisture gradients remained stable at about $16 \%$ throughout ripening, and probably accounted for differences among the proteolytic measures in the same layers. The mechanism involved likely has to do with decreases in microbial survival and enzymatic activities at lower moisture contents. Decreasing moisture produces a lowering of water activity and, consequently, enzymatic activities are limited. For example, Horne et al. (unpublished) found that decreasing moisture contents in Ragusano cheeses were important in lessening bitter and sour offtastes that result from early microbial activity. Kristiansen et al. (1999) reported a positive association between $\mathrm{pH}$ and moisture in Danbo-type cheeses that is consistent with results found here. If the more alkaline $\mathrm{pH}$ resulted from increased levels of ammonia and other alkaline proteolytic products, then this relationship between $\mathrm{pH}$ and moisture would support the hypothesis that proteolysis and moisture levels are integrally tied together. The very strong negative correlation between moisture and total protein $(R=-0.967)$ and the positive correlations between moisture and most of the proteolytic measures (Table 2) also support this hypothesis.

Similar, albeit usually weaker, relationships were found between S/M and proteolysis. These were likewise attributable to a relatively constant rind-to-core $\mathrm{S} / \mathrm{M}$ gradient at the different ripening times. The fact that this gradient still existed after 7 mo ripening ( $1.1 \%$ compared with $1.4 \%$ after $3 \mathrm{mo}$ ) was probably due to the brine salting technique used in Ragusano cheese production. Lee et al. (1980) noted that brine-salted cheeses required a much longer time to attain uniform salt distributions than did those that were dry salted after the milling step. Similar S/M gradients have been found by several others working with brine-salted Italian cheeses (Fox and Guinee, 1987; Gobbetti et al., 1997). The absolute S/M contents reported here were also consistent with those found in other PDO Ragusano cheeses (Licitra et al., 2000).

The effect $\mathrm{S} / \mathrm{M}$ had on proteolysis again was likely to have been due to the effect of moisture. Increasing S/ $\mathrm{M}$ is known to inhibit rennet and microbial activities
(Fox and Guinee, 1987), and the significant negative correlations between $\mathrm{S} / \mathrm{M}$ and some of the proteolytic measures found in the current study (Table 2) appear to confirm this idea. Melilli et al. (2004) also reported significant increases in $\mathrm{pH} 4.6 \mathrm{SN}$ and TCASN from the rind to the core in Ragusano cheeses and attributed those differences to large $\mathrm{S} / \mathrm{M}$ gradients ranging from 8.2 to $9.8 \%$. Other researchers have reported similar relationships in Cheddar and Romano-type cheeses (Guinee and Fox, 1984; Kelly et al., 1996). In the present work, S/M and thus the S/M gradients were far more functions of moisture content than they were of salt content. This is demonstrated by the patterns of intercorrelations (Table 2). Had salt contents been the principal drivers of the salt-to-moisture ratios, we would have expected positive relationships with the proteolytic measures because salt itself was positively associated with these measures. Instead, we found negative relationships between $\mathrm{S} / \mathrm{M}$ and all 5 of the proteolytic measures, although 2 were nonsignificant, which suggests that moisture had the greater influence. Therefore, the current results appear to indicate that differences in proteolysis due to $\mathrm{S} / \mathrm{M}$ are just as easily attributable to moisture by itself.

Fat in dry matter (FDM) content did not appear to exert an influence on proteolysis. No significant differences were found between cheese layers, which confirms the results of Licitra et al. (2000). There was likewise no significant linear trend between FDM and ripening time. Fat in DM was significantly correlated with only TCASN/pH4.6SN $(\mathrm{R}=+0.55)$. Fat in DM levels exceeded the minimum required for PDO Ragusano cheeses (40\%, wt/wt) (Gazzetta Ufficiale Repubblica Italiana, 1995) in all samples tested.

Among the individual measures of proteolysis, the strongest relationships between other chemical parameters such as $\mathrm{pH}$, moisture, and salt were found with $\mathrm{pH} 4.6 \mathrm{SN}$ and TCASN. These 2 variables were likewise strongly and positively correlated with one another $(\mathrm{R}=$ $+0.94)$. Significant rind-to-core differences were found among these 2 measures as well as among the ammonia means (Table 1). Both measures increased significantly with ripening time $\left(\mathrm{F}_{1,43}>7.9\right)$, although a much stronger effect was seen between $\mathrm{pH} 4.6 \mathrm{SN}$ and ripening time (partial $R^{2}=0.195$ ) than was seen between TCASN and ripening time (partial $\mathrm{R}^{2}=0.127$ ). These measures are widely used as indices of proteolysis, both to quantify casein hydrolysis and to understand the contribution of enzymatic activities from coagulant, milk, and microflora to this process. The majority of $\mathrm{pH} 4.6 \mathrm{SN}$ is made up of large- and medium-sized peptides produced by the action of residual rennet and plasmin, but it also contains numerous small-sized peptides, FAA and their catabolites produced by microflora. Nitrogen soluble in 
$12 \%$ TCA, on the other hand, consists primarily of small-sized peptides, FAA, and other minor nitrogenous compounds produced by both starter and nonstarter bacteria (Fox et al., 1993). A high proportion of pH4.6SN in the current study was also soluble in $12 \%$ TCA, confirming previously reported results for Ragusano cheese (Fallico et al., 2003a, 2003b). Age-adjusted weighted TCASN/pH4.6SN means from the different layers ranged from 80.8 ( \pm 0.75 standard errors) to $85.0 \%$ ( \pm 1.26 standard errors). Even at early stages of ripening, most of the pH4.6SN in Ragusano cheeses is made up of TCASN, with the highest ratios reached after $4 \mathrm{mo}$ (results not shown). These results then point to the early production of a considerable amount of low molecular mass peptides ( 2 to 20 amino acids), favored by high moisture contents. The production of these small peptides is important in the formation of cheese flavor (Sousa et al., 2001). The high proportions of TCASN/ $\mathrm{pH} 4.6 \mathrm{SN}$ are also indicative of the major role played by adventitious bacteria, which are largely responsible for the production of TCASN, in Ragusano cheese ripening.

\section{Electrophoretic Analysis}

Urea-PAGE of the $\mathrm{pH}$ 4.6-insoluble $\mathrm{N}$ fraction of Ragusano cheese layers at selected ages is shown in Figure 1 . The extent of casein proteolysis was affected by both cheese layer and age. Moderate hydrolysis of $\alpha_{\mathrm{s} 1}-\mathrm{CN}$ and $\beta$-CN were common features of both 3 - and 4-mo aged cheese profiles. Cheese layer had a major impact on proteolysis level at these times. The cheese surface showed slight hydrolysis of native caseins, which were progressively more degraded in the inner layers. Proteolysis largely increased in cheeses at 6 and 7 mo of age, with the inner layers always showing higher levels of $\alpha_{\mathrm{s} 1}-\mathrm{CN}$ and $\beta$-CN degradation than the outer layers.

Plasmin action on $\beta$-CN was likely responsible for increasing levels of $\beta$-CN f29-209 $\left(\gamma_{1}-\mathrm{CN}\right), \beta$-CN f106$209\left(\gamma_{2}-\mathrm{CN}\right)$ and $\beta$-CN f108-209 $\left(\gamma_{3}-\mathrm{CN}\right)$ (Sousa et al., 2001) from the rind to the core of the cheeses. The production of $\gamma$-CN was also positively related with Ragusano cheese age, as the relative intensities of the bands increased with ripening time at each selected layer. Rennet activity on $\beta$-CN produced 2 peptides, $\beta$ CN f1-192 ( $\beta$-I) and an unidentified fragment, migrating in the same region as $\beta$-CN and showing a slightly higher mobility than native protein. Their levels were affected by both cheese layer and age, increasing in the innermost layers and throughout ripening. Similar peptides were detected in Gouda cheese made with different amounts of rennet, increasing in intensity with coagulant concentrations (Visser, 1993). Three peptides moving slower than $\gamma$-CN were detected at each level of ripening. In a previous work, we showed that these fragments were probably produced from $\beta$-CN by the action of plasmin or microbial proteinases with a trypsin-like activity. These same fragments have been recognized by polyclonal antibodies specific for $\beta-\mathrm{CN}$ and produced exclusively by plasmin during in vitro hydrolysis of whole casein with isolated dairy proteases (Fallico et al., 2003b).

Hydrolysis of $\alpha_{\mathrm{s} 1}$-CN produced a number of peptides moving faster than native casein. It has been shown that these fractions are mainly proteolysis products of $\alpha_{\mathrm{s} 1}$-CN (McSweeney et al., 1993; Fallico, et al., 2003b) due to rennet action. Residual chymosin (or perhaps cathepsin D) activity produced the primary peptide $\alpha_{\mathrm{s} 1^{-}}$ CN f24-199 $\left(\alpha_{\mathrm{s} 1}-\mathrm{I}\right)$, showing the greatest levels in 3- and 4 mo-old cheeses and in the innermost layers. The $\alpha_{\mathrm{s} 1^{-}}$ I in Cheddar cheese is further hydrolyzed by chymosin at the bond $\mathrm{Leu}_{101}-\mathrm{Lys}_{102}$ (Sousa et al., 2001). The gradual decrease of $\alpha_{\mathrm{s} 1}$-I level, as Ragusano cheese aged, was then related to the production of $\alpha_{\mathrm{s} 1}-\mathrm{CN}$ f102-199, with lower mobility than $\alpha_{\text {s1-I. }}$. Cheese layer also affected the level of $\alpha_{\mathrm{s} 1}-\mathrm{CN}$ f102-199, gradually increasing in the innermost layers of 6- and 7 mo-old cheeses. Finally, the greater extent of $\alpha_{\mathrm{s} 1}$-CN hydrolysis at these times produced a number of peptides having the highest electrophoretic mobility.

Proteolysis of $\alpha_{\mathrm{s} 1}$-CN and $\beta$-CN in Ragusano cheese was affected by both cheese layer and age, with a major influence of chemical parameters on the layer-related hydrolysis. Increasing levels of peptides, found from the rind to the core of the cheeses, were associated with layers having higher $\mathrm{pH}$, moisture and salt contents. Moisture probably plays a major role in affecting protease activity on caseins, as increasing moisture contents, and consequently higher water activity, are known to support enzyme activities (Kristiansen et al., 1999). Higher levels of $\gamma$-CN in the inner layers of Ragusano cheese were probably due to increasing moisture contents, but other factors also tend to be advantageous for plasmin action on $\beta$-CN. The increase in cheese $\mathrm{pH}$ has been shown to influence the degree of hydration and aggregation of $\beta$-CN resulting in a modified susceptibility to hydrolysis by proteases (Creamer, 1985). Kelly et al. (1996) reported a positive relationship between the amount of $\gamma$-CN and $\mathrm{pH}$ values in Cheddartype cheese. The $\mathrm{pH}$ was positively associated with moisture in Ragusano cheese and both had positive correlations with most of the indices of proteolysis. Further, the amounts of $\gamma-\mathrm{CN}$ in Ragusano cheese increased with salt content. Kelly et al. (1996) showed that plasmin activity on $\beta$-CN was also positively influenced by salt concentration. Similarly, higher levels of $\gamma$-CN were found in Danbo-type salted cheeses compared with the unsalted (Kristiansen et al., 1999). 


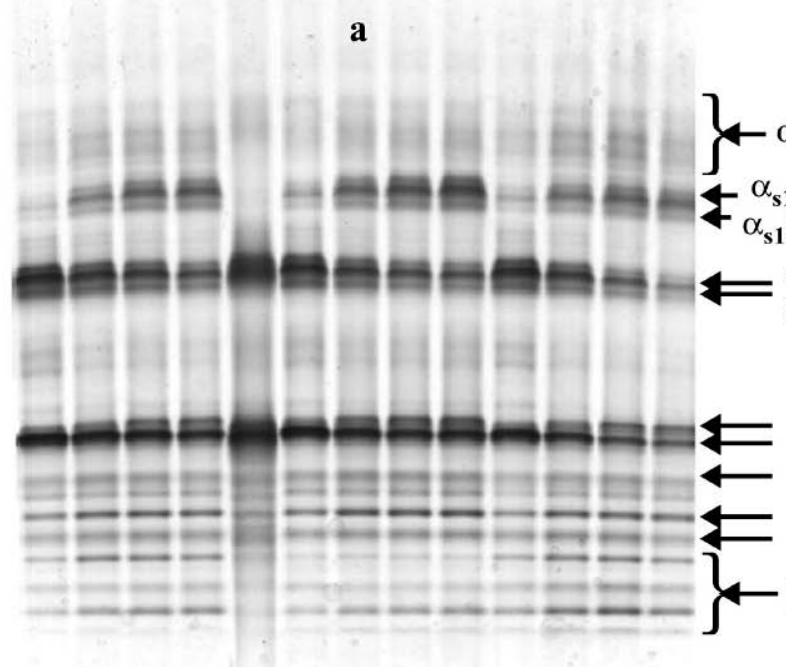

3R 3E 3M 3I CN 3R 3E 3M 3I 3R 3E 3M 3I b

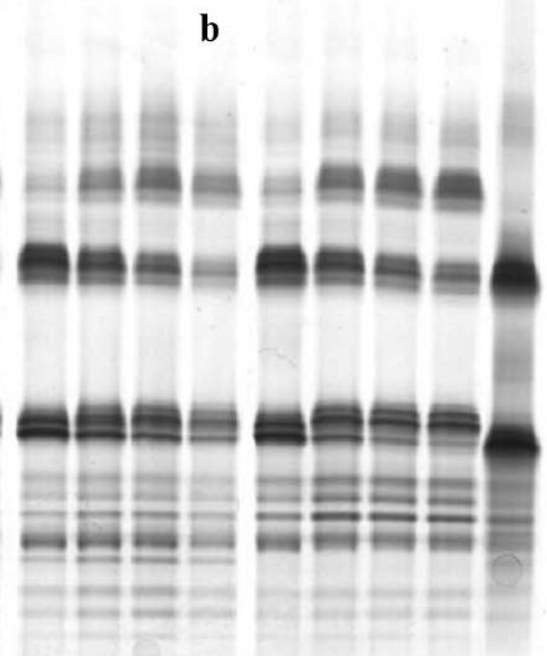

4R 4E 4M 4I 4R 4E 4M 4I 4R 4E 4M 4I CN

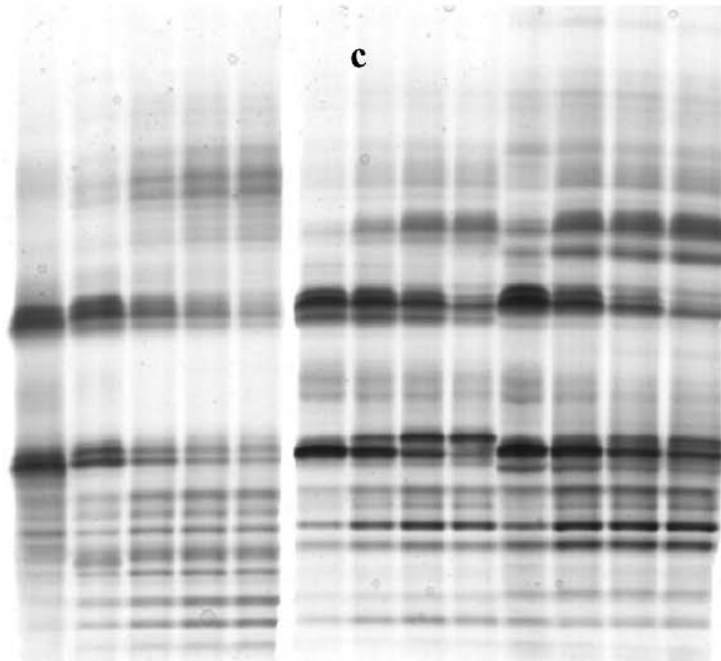

CN 6R 6E 6M 6I 6R 6E 6M 6I 6R 6E 6M 6I

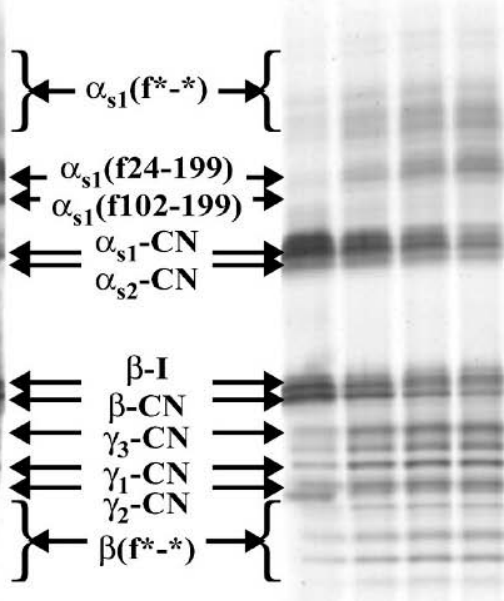

7R 7E 7M 7I 7R 7E 7M 7I d

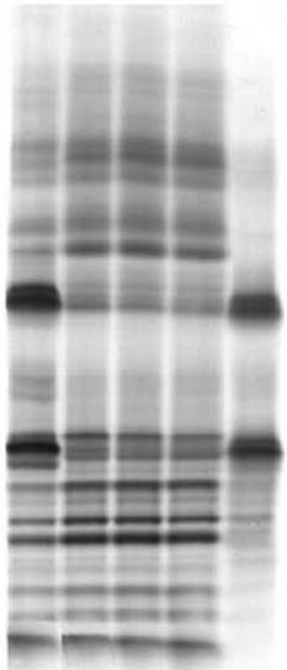

7R 7E 7M 7I CN

Figure 1. Urea-polyacrylamide gel electrophoretograms $(\mathrm{pH} 8.6)$ of the $\mathrm{pH}$ 4.6-insoluble $\mathrm{N}$ fraction from selected layers $(\mathrm{R}=$ rind, $\mathrm{E}=$ external, $\mathrm{M}$ = middle, I = internal) of PDO Ragusano cheese after 3 (a), 4 (b), 6 (c), and 7 (d) mo of age. Analyses were in triplicate.

The influence of salt concentration on coagulant activity was more complex, as reflected in varying rates of hydrolysis of the caseins. It has been reported that variations of the salt content in cheese influence the ability of chymosin to degrade $\beta$-CN (Fox and Walley, 1971), while the degradation of $\alpha_{\mathrm{s} 1}$-CN was not affected to the same extent (Mulvihill and Fox, 1979). Hydrolysis of $\alpha_{\mathrm{s} 1}{ }^{-} \mathrm{CN}$ in Ragusano cheese increased throughout ripening and in the inner layers at each time. Production of $\alpha_{\mathrm{s} 1}$-I and $\alpha_{\mathrm{s} 1}$-CN f102-199 was therefore positively related with increasing salt content of the cheese, as previously observed by others (McSweeney et al., 1993; Kelly et al., 1996). Salt concentration mainly af- fected chymosin action on $\beta$ - $\mathrm{CN}$ in Ragusano cheese. Profiles of 3 - and 4-mo-old cheeses with $<5 \%$ S/M showed a great extent of $\beta$-CN degradation with the larger production of $\beta$-I. The large hydrolysis of $\beta$-CN in 6- and 7-mo old cheeses, with $>5 \% \mathrm{~S} / \mathrm{M}$, was instead more related to $\gamma$-CN production by plasmin. Fox and Walley (1971) observed that proteolysis of $\beta$-CN by coagulant was significantly reduced by $5 \% \mathrm{~S} / \mathrm{M}$ and completely inhibited in the presence of $10 \% \mathrm{~S} / \mathrm{M}$.

\section{RP-HPLC Chromatograms of IP and SP}

The IP fraction of Ragusano cheese in 4 different layers at selected ages was analyzed by RP-HPLC (re- 
sults not shown). The chromatograms displayed a high number of medium molecular weight peptides, uniformly spread over the central and hydrophobic zones of the acetonitrile gradient. Two main peaks dominated the $70 \%$ ethanol-insoluble $\mathrm{N}$ profiles of Ragusano cheese, eluting in the very hydrophobic region between 50 and $60 \mathrm{~min}$.

Analysis by RP-HPLC of the SP fraction of Ragusano cheese (results not shown) provided peptide profiles similar to those reported for Parmigiano-Reggiano (Noël et al., 1998). Low molecular weight compounds of Ragusano cheese were contained within 4 peaks eluting within the first $30 \mathrm{~min}$. Cheese age had no effect on the qualitative peptide profile of Ragusano cheese but increasing levels of low molecular weight peptides were found from the cheese surface to the core. This finding relates well with the data trend for the TCASN (Table 1), which is reported to contain similar peptides to those in the $70 \%$ ethanol-soluble cheese fraction (Kuchroo and Fox, 1982). Levels of TCASN constantly increased from the outer to the inner layers during cheese ripening $(+43 \%,+55 \%,+70 \%$ and $+73 \%$ at $3,4,6$, and 7 mo, respectively).

\section{Individual FAA}

Analysis of raw data showed that absolute amounts of FAA varied to a large extent according to cheese age, layer, and origin, agreeing with previous reports (McSweeney and Fox, 1993; Krause et al., 1997; Bütikofer and Fuchs, 1997). The mean concentrations of individual FAA (milligrams per gram of cheese) in the 4 layers of PDO Ragusano cheese at various ages are shown in Figure 2. The principal FAA in all cheese layers at most ripening times were Glu, Lys, Leu, Pro, Val, Phe, Ile and Ser, accounting for 81 to $83 \%$ of the total FAA content. Similar amino acid profiles have been reported previously for different cheese varieties. High levels of the same individual FAA were found in Parmigiano-Reggiano (Battistotti and Corradini, 1993) and, with the exception of Phe and Ile, in Canestrato Pugliese (Albenzio et al., 2001). Polo et al. (1985) reported Glu, Val, Phe, Ile, and Pro as the main FAA in 4-mo ripened Mahn cheese, accounting for between 67 and $80 \%$ of total FAA.

Among the 8 principal FAA in Ragusano cheese, Glu, Lys, and Leu accounted for $48 \%$ of total FAA. They were also the main FAA in Provolone at 5 to 6 mo of age (Battistotti and Corradini, 1993) and in 2-mo ripened Caciocavallo Silano (Corsetti et al., 2001) cheese, both pasta filata cheeses similar to Ragusano. Glutamic acid was the FAA with the largest concentration in all Ragusano cheese samples at each time. Its absolute amount, ranging from about $4 \mathrm{mg} / \mathrm{g}$ at $3 \mathrm{mo}$ to $6 \mathrm{mg} / \mathrm{g}$ at $7 \mathrm{mo}$, was always at least twice as large as either of the other 2 most abundant FAA, Lys and Leu. Because of its flavor-enhancing properties (Krause et al., 1997), glutamic acid might contribute to the development of Ragusano cheese flavor. Leucine might also be an important precursor of branched-chain volatile flavor compounds (Fox and Guinee, 1987).

Nonsignificant increases with cheese age and layer were found for the levels of individual FAA in Ragusano cheese (results not shown). The amount of total FAA ranged from $14.3 \mathrm{mg} / \mathrm{g}$ at $3 \mathrm{mo}$ to $22.0 \mathrm{mg} / \mathrm{g}$ after $7 \mathrm{mo}$, representing the $6.2 \%$ to $8.4 \%$ of total protein. The same ratio in 2-mo ripened Caciocavallo Silano cheese varied from 4.7 to $8.6 \%$ (Corsetti et al., 2001), while in Provolone cheese after 5 to 6 mo of ripening it ranged from 8.2 to $16.6 \%$ (Battistotti and Corradini, 1993).

\section{PCA and HCA of Reversed Phase-HPLC Chromatograms of Peptides}

Exploratory data analysis of HPLC chromatograms of peptides was performed to evaluate the influence of layer and age on proteolysis of PDO Ragusano cheeses. Principal component analysis and HCA were first applied to the IP data set, consisting of 58 recognized peaks. The first 11 principal components contained the meaningful variance in the data set (based on eigenvalue $>1$ ), and represented $89.3 \%$ of the total variance. Scores of the first 2 principal components, cumulatively accounting for $47.3 \%$ of the variance, were normalized and plotted, as shown in Figure 3. The PCA biplot arranged cheese samples into 2 major groups, analogous to the pattern identified by HCA (results not shown). All the samples contained in the large cluster were from cheeses produced by the same farm, while the small cluster grouped layers from 2 cheeses each derived from different farms. Variables with factor loadings higher than 0.8 were plotted on the normalized score plot. The high loading value for the farm variable on factor 1 indicated that grouping of cheeses into separate clusters along the PC1 axis was largely according to the farm origin. Based on variables with high loading values, a group of 8 IP peaks were associated with the separation of the samples between the 2 clusters. These peaks corresponded to hydrophobic peptides since they eluted at high acetonitrile concentrations in the RPHPLC profiles. Differences in the most hydrophobic peptides were also found to differentiate between RPHPLC peptide mappings of Appenzeller and Parmigiano-Reggiano cheeses (Noël et al., 1998). High loading values for 2 peaks with medium hydrophobicity separated, on the PC2 axis, 3-mo aged cheeses from the other samples of the large cluster. 

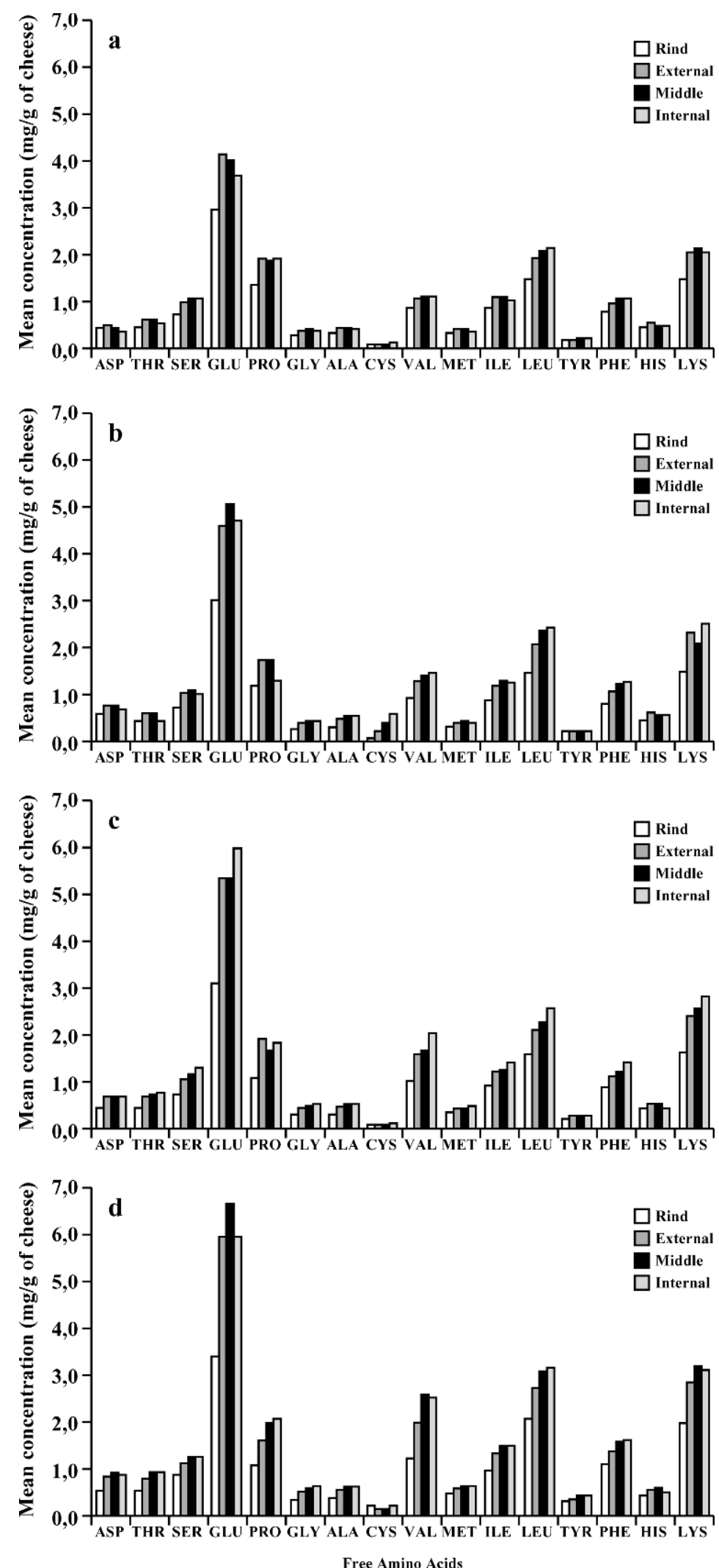

Figure 2. Mean levels $(\mathrm{n}=3)$ of individual free amino acids $(\mathrm{mg} / \mathrm{g}$ cheese $)$ in 4 selected layers $(\mathrm{R}=$ rind, $\mathrm{E}=\mathrm{external}, \mathrm{M}=\mathrm{middle}, \mathrm{I}=$ internal) of PDO Ragusano cheese after 3 (a), 4 (b), 6 (c), and 7 (d) mo of age. 


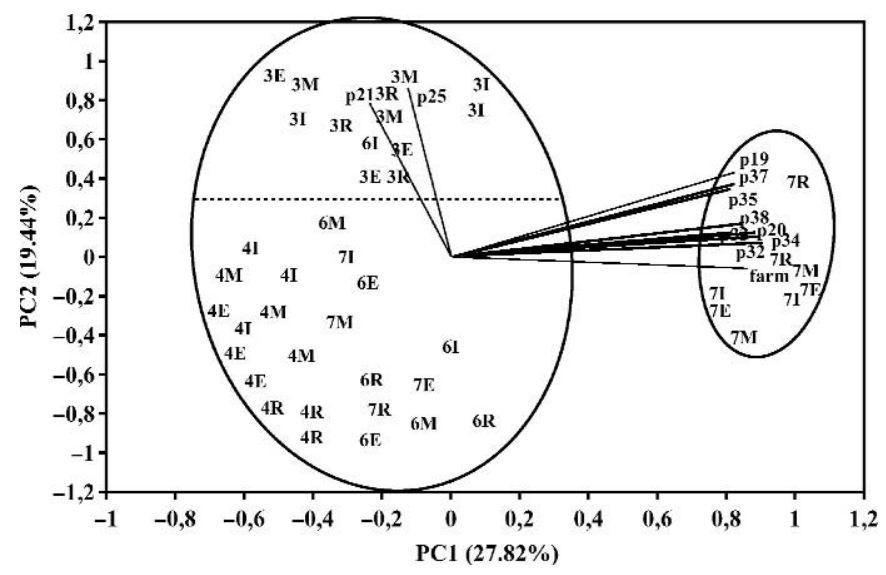

Figure 3. Biplot of normalized scores and loading vectors of variables with high loading obtained by principal component analysis of data from reversed-phase-HPLC chromatograms of the 70\% ethanolinsoluble peptides from selected layers $(\mathrm{R}=$ rind, $\mathrm{E}=$ external, $\mathrm{M}=$ middle, I = internal) of PDO Ragusano cheese after 3, 4, 6, and 7 mo of age.

Nine principal components were adequate to represent $90.1 \%$ of the variance in the SP data set, consisting of 57 recognized peaks. The score plot of PC1 vs. PC2, which accounted for $63.2 \%$ of the data variation, is shown in Figure 4. A tendency for cheese samples to group according to the farm origin was again observed on the PC1 axis, as previously reported for IP. The dendrogram from HCA (results not shown) showed 2 main clusters of similarity, with the larger one enclosing cheeses produced on one farm, while the smaller

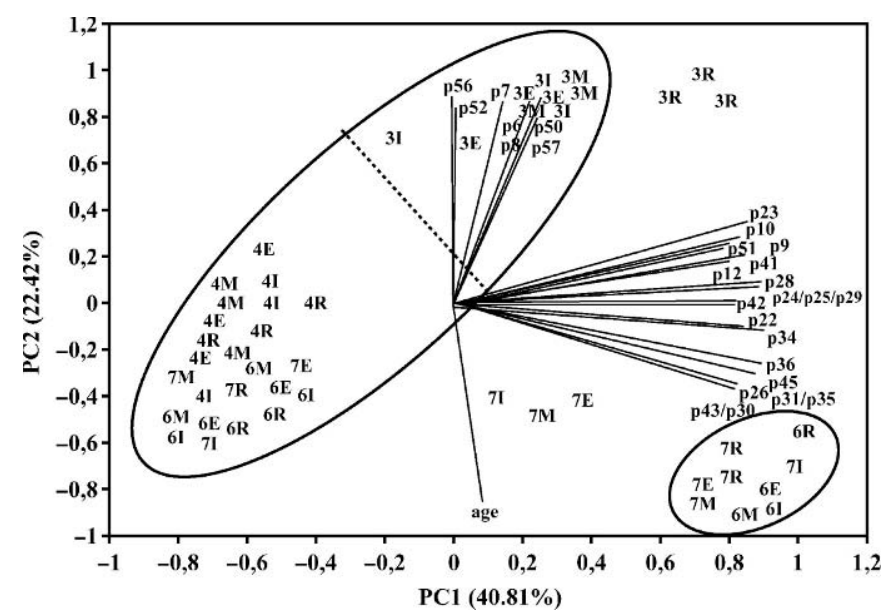

Figure 4. Biplot of normalized scores and loading vectors of variables with high loading obtained by principal component analysis of data from reversed-phase-HPLC chromatograms of the 70\% ethanolsoluble peptides from selected layers $(\mathrm{R}=$ rind, $\mathrm{E}=$ external, $\mathrm{M}=$ middle, I = internal) of PDO Ragusano cheese after 3, 4, 6, and 7 mo of age.

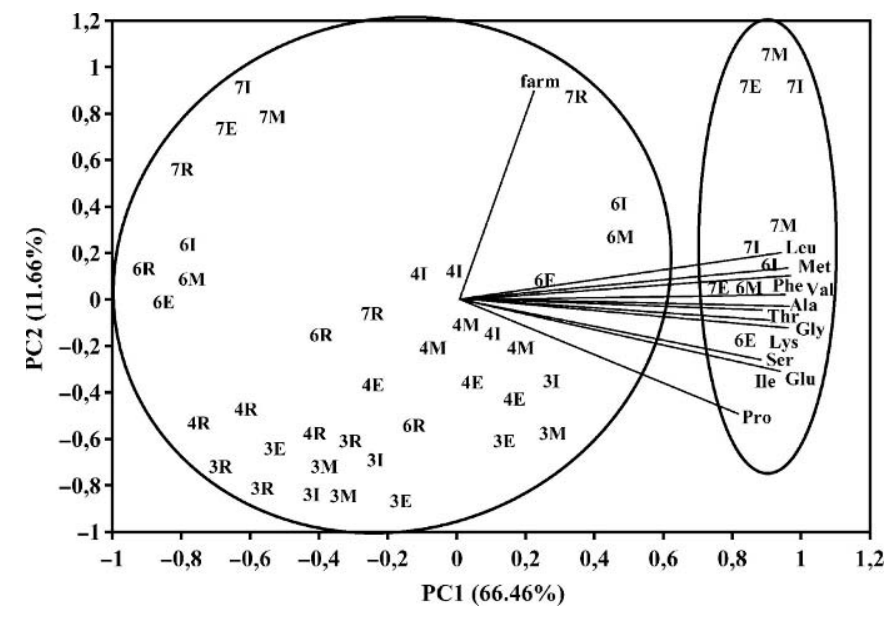

Figure 5. Biplot of normalized scores and loading vectors of variables with high loading obtained by principal component analysis of free amino acids content from selected layers $(\mathrm{R}=$ rind, $\mathrm{E}=$ external, $\mathrm{M}=$ middle, $\mathrm{I}=$ internal) of PDO Ragusano cheese after 3, 4, 6, and 7 mo of age.

cluster grouped cheeses having different farm origins. Based on variables with loading values higher than 0.8 , most of the peaks accounting for the differences among clusters were hydrophobic, having retention times higher than $35 \mathrm{~min}$, while 3 of the peaks eluted in the hydrophilic zone of the chromatograms. Cheeses grouped by age along PC2, as confirmed by the high negative correlation of the age variable with the same axis. With the exception of the rind samples, cheeses at 3 mo of age were separated into a subgroup within the main cluster because of the high loading values for (3) hydrophilic and (4) hydrophobic peaks. The HCA also showed that rind samples at $3 \mathrm{mo}$ and the external, medium and internal layers of a 7-mo-old sample had a high similarity with samples of the major cluster.

\section{PCA and HCA of FAA}

Principal component analysis (Figure 5) and HCA (results not shown) of individual FAA data separated the external, medium, and internal layers of one 6-moold and 2 7-mo-old cheeses into a small cluster and the remainder of the samples in a larger one. Loading vectors of variables with loading values higher than 0.8 showed that, with the exceptions of Asp, Cys, Tyr, and His, cheese layers within the small cluster had higher concentrations of most FAA than the other samples. A high loading value for the farm variable, positively correlated with PC2 axis, also in PCA analysis of FAA data confirmed that farm origin greatly influenced production of soluble compounds in PDO Ragusano cheese. However, the low percentage of variance explained by 
Table 3 Results from partial least square regression modeling of cheese age as a function of amino acid and peptide concentrations.

\begin{tabular}{lllll}
\hline Data set & $\mathrm{n}^{1}$ & $\mathrm{R}^{22}$ & $\mathrm{Q}^{23}$ & Components $^{4}$ \\
\hline FAA $^{5}$ & 48 & 0.548 & 0.502 & 2 \\
SP $^{6}$ & 46 & 0.899 & 0.864 & 3 \\
$\mathrm{IP}^{7}$ & 47 & 0.937 & 0.876 & 4 \\
$\mathrm{FAA}+$ SP & 46 & 0.945 & 0.886 & 3 \\
FAA + IP & 46 & 0.939 & 0.872 & 3 \\
SP + IP & 45 & 0.961 & 0.923 & 4 \\
FAA + SP + IP & 43 & 0.976 & 0.952 & 3 \\
\hline
\end{tabular}

${ }^{1}$ Number of observations used after removal of outliers.

${ }^{2}$ Multiple correlation coefficient squared.

${ }^{3}$ Cross-validated multiple correlation coefficient squared.

${ }^{4}$ Optimal number of PLS components selected by cross-validation.

${ }^{5} \mathrm{FAA}=$ Free amino acids.

${ }^{6} \mathrm{SP}=70 \%$ ethanol-soluble peptides.

${ }^{7} \mathrm{IP}=70 \%$ ethanol-insoluble peptides.

PC2 suggested that FAA were less influential than peptide data in differentiating cheeses by farm.

\section{Models of Cheese Age}

Construction of a model of cheese age as a function of the analytical results is an inverse process because age is actually the independent variable that results in the changes in the peptide and amino acid patterns. Inverse modeling has long been used in many applications, perhaps most notably calibration models (Beebe et al., 1998). The data sets obtained in this study all have more measurements than the number of samples and are thus highly over-determined. This is problematic for many methods of multivariate analysis (Wold et al., 1984). Methods that employ PCA as part of the procedure, however, effectively reduce the number of measurements and increase the sample to measurement ratio. PLSR and PLSDA procedures typically use cross validation, a method of internal validation using the original data set, to test for the optimal number of principal components to use (Wold, 1978).

The results for PLS models of sample age as a function of the measurements are shown in Table 3. The FAA data set was the poorest in modeling sample age as shown by the low $\mathrm{R}^{2}$ and $\mathrm{Q}^{2}$. In the case of regression methods (Wold et al., 2001), the multiple correlation coefficient squared $\left(\mathrm{R}^{2}\right)$ is considered to represent the proportion of the variance explained by the model (model fit). The cross validated $\mathrm{R}^{2}\left(\mathrm{Q}^{2}\right)$ represents the ability of a model to make predictions with new data (model predictive ability). Peptide profiles were much better in modeling sample age, with the IP data set being the best of the three. Including FAA data with the SP or the IP produced slight improvement of the fit $\left(\mathrm{R}^{2}\right)$ or the predictive ability $\left(\mathrm{Q}^{2}\right)$ of the corresponding models. The best 2 -way combination was the combined

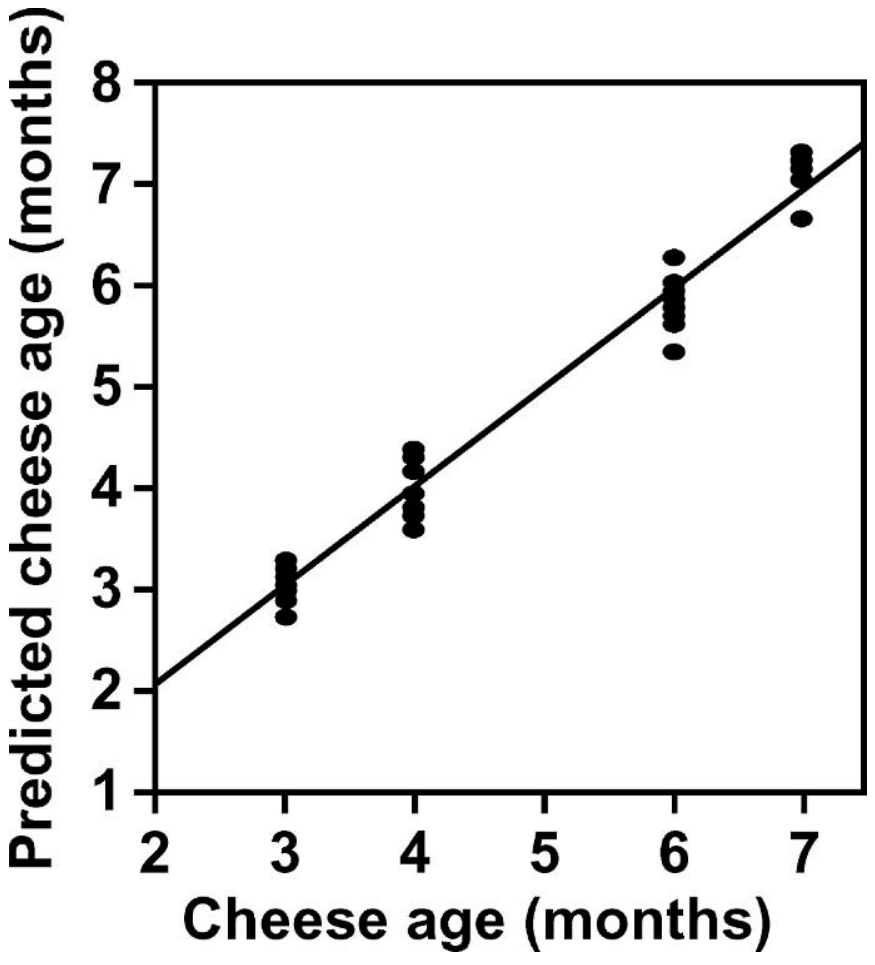

Figure 6. Comparison of actual and predicted cheese age from the model $\left(\mathrm{R}^{2}=0.976, \mathrm{Q}^{2}=0.952\right)$ constructed from all 3 sets of measurements ( $70 \%$ ethanol-soluble peptides, $70 \%$ ethanol-insoluble peptides and free amino acids).

SP and IP data set. The combination of all 3 data sets resulted in the strongest model for predicting cheese age. In this model, all results from one 7-mo-old cheese were considered outliers in the normal probability plot and were removed from the data set. A plot showing the actual cheese age and that predicted from the model based on the combined analytical data is shown in Figure 6. The model was based on 3 PLS components (Table 3 ); that means that, although all of the measurements were used, only 3 fundamental properties were needed to make the predictions. Each of these was a different linear combination of all the original measurements.

The SIMCA-S program provides a statistic that permits comparison of the relative influence of predictors, called the variable influence on the projection (VIP). Examining the VIP values for the model and the arithmetic signs of the corresponding coefficients is informative about the directional effect of the more important measurements. The 20 most important predictors were all peptides and most had negative signed coefficients. The FAA were much less important in the model, but all except Cys had positive signed coefficients. These findings are related to the tendency of the peptides to diminish in concentration with age because of their hydrolysis and to the consequent production of FAA. 
Table 4. Results of partial least squares discriminant analysis classification of samples by age. Probability of correct classification by chance in each case was $25 \%$.

\begin{tabular}{|c|c|c|c|c|c|c|}
\hline Data set & $\mathrm{n}^{1}$ & $\mathrm{~m}^{2}$ & $\mathrm{R}^{23}$ & $\mathrm{Q}^{24}$ & Components $^{5}$ & $\begin{array}{l}\text { Classification } \\
\text { success }(\%)\end{array}$ \\
\hline FAA $^{6}$ & 48 & 18 & 0.386 & 0.324 & 3 & 64.6 \\
\hline $\mathrm{SP}^{7}$ & 48 & 57 & 0.806 & 0.710 & 5 & 93.8 \\
\hline $\mathrm{IP}^{8}$ & 47 & 58 & 0.843 & 0.657 & 5 & 97.9 \\
\hline $\mathrm{FAA}+\mathrm{SP}$ & 47 & 75 & 0.824 & 0.732 & 3 & 93.6 \\
\hline $\mathrm{FAA}+\mathrm{IP}$ & 47 & 76 & 0.731 & 0.636 & 4 & 89.4 \\
\hline $\mathrm{SP}+\mathrm{IP}$ & 47 & 115 & 0.901 & 0.806 & 6 & 100 \\
\hline $\mathrm{FAA}+\mathrm{SP}+\mathrm{IP}$ & 47 & 133 & 0.903 & 0.789 & 6 & 97.9 \\
\hline
\end{tabular}

${ }^{1}$ Number of observations used after removal of outliers.

${ }^{2}$ Number of measurements in data sets.

${ }^{3}$ Multiple correlation coefficient squared.

${ }^{4}$ Cross-validated multiple correlation coefficient squared.

${ }^{5}$ Optimal number of partial least squares components selected by cross-validation.

${ }^{6} \mathrm{FAA}=$ Free amino acids.

${ }^{7} \mathrm{SP}=70 \%$ ethanol-soluble peptides.

${ }^{8} \mathrm{IP}=70 \%$ ethanol-insoluble peptides.

The most important predictors were $5 \mathrm{SP}$ and $5 \mathrm{IP}$ peaks. All of the SP peaks but one had high retention times on the reversed-phase column and are thus relatively nonpolar. The IP peaks were mainly of medium retention behavior and thus medium relative polarity.

\section{Classification of Samples by Age}

The PLSDA was applied to the samples in an attempt to classify them according to their age. The results are shown in Table 4. Samples were classified according to the group for which they had the best match. This can be expressed in terms of the percentage of the samples assigned to the correct class. As with the regression fit of sample age, the poorest performance was with the FAA data set. The SP data were better and IP performed best (97.9\%). Adding FAA and SP to IP data produced no change in performance. The best performance, $100 \%$ correct classification, was seen with the combination of SP and IP data. The 3-mo aged cheeses were all correctly classified with all 7 data sets. The 4mo cheeses were correctly classified in all the data sets except the FAA, while the 6-mo and particularly the 7mo cheeses were more problematic. A plot of the relationships between samples based on the classification using SP and IP is shown in Figure 7. The 3-mo cheeses were widely separated from the rest, and there was some overlap of the 6- and 7-mo samples, at least on the first 2 principal components. Examination of VIP values revealed that 6 of the 10 most discriminatory compounds for distinguishing between sample classes were SP, with 2 of these being relatively polar and the others quite hydrophobic. The other 4 peaks were IP, 2 of which were relatively polar and the other 2 fairly nonpolar.

\section{Classification of Samples by Farm}

Results from the exploratory analysis of peptide and FAA data revealed that the farm origin might be used as a variable for differentiating and classifying Ragusano cheese. The PLSDA was applied to the samples in an attempt to classify them according to the farm where they were made (Table 5). Of the 12 cheeses, 9 were

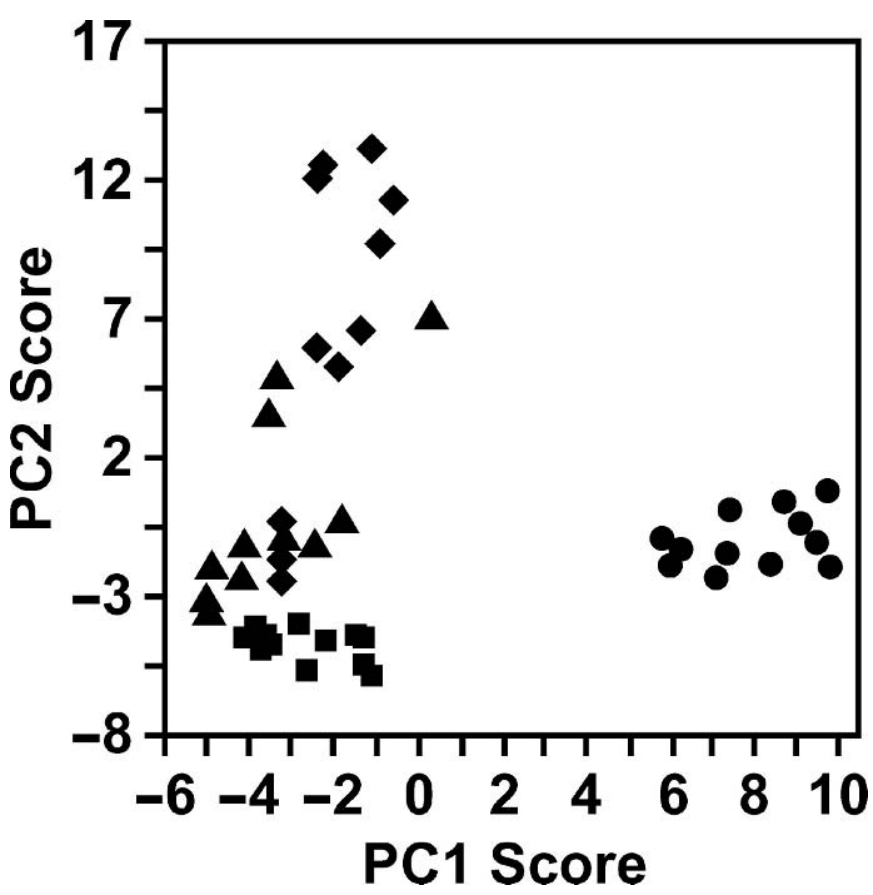

Figure 7. The distribution of the cheese samples classified according to age ( $3 \mathrm{mo} ; 4 \mathrm{mo} ; \boldsymbol{\Delta} 6 \mathrm{mo} ; 7 \mathrm{mo})$ by partial least squares discriminant of combined $70 \%$ ethanol-soluble and -insoluble peptides. 
Table 5. Results of partial least squares discriminant analysis classification of samples by farm. Probability of correct classification by chance in each case was $33.3 \%$.

\begin{tabular}{|c|c|c|c|c|c|c|}
\hline Data set & $\mathrm{n}^{1}$ & $\mathrm{~m}^{2}$ & $\mathrm{R}^{23}$ & $\mathrm{Q}^{24}$ & Components $^{5}$ & $\begin{array}{l}\text { Classification } \\
\text { success }(\%)\end{array}$ \\
\hline $\mathrm{FAA}^{6}$ & 48 & 18 & 0.720 & 0.605 & 5 & 100 \\
\hline $\mathrm{SP}^{7}$ & 48 & 57 & 0.963 & 0.886 & 6 & 100 \\
\hline $\mathrm{IP}^{8}$ & 47 & 58 & 0.888 & 0.697 & 6 & 100 \\
\hline $\mathrm{FAA}+\mathrm{SP}$ & 47 & 75 & 0.976 & 0.926 & 7 & 100 \\
\hline $\mathrm{FAA}+\mathrm{IP}$ & 47 & 76 & 0.921 & 0.806 & 7 & 100 \\
\hline $\mathrm{SP}+\mathrm{IP}$ & 47 & 115 & 0.979 & 0.929 & 7 & 100 \\
\hline $\mathrm{FAA}+\mathrm{SP}+\mathrm{IP}$ & 47 & 133 & 0.965 & 0.917 & 6 & 100 \\
\hline
\end{tabular}

${ }^{1}$ Number of observations used after removal of outliers.

${ }^{2}$ Number of measurements in data sets.

${ }^{3}$ Multiple correlation coefficient squared.

${ }^{4}$ Cross-validated multiple correlation coefficient squared.

${ }^{5}$ Optimal number of partial least squares components selected by cross-validation.

${ }^{6} \mathrm{FAA}=$ Free amino acids

${ }^{7} \mathrm{SP}=70 \%$ ethanol-soluble peptides.

${ }^{8} \mathrm{IP}=70 \%$ ethanol-insoluble peptides.

from one farm (designated 1), and the other 3 were each from different farms (designated 2, 3, and 4). Although there were data for 4 layers for each cheese, this meant that there was only one cheese representing each of 3 farms. Classification by farm was $100 \%$ successful with each set of the data. Examination of the results indicated that classification by SP was somewhat sharper (better separation of the classes, $\mathrm{Q}^{2}=$ $0.886)$ than with either the IP $\left(\mathrm{Q}^{2}=0.697\right)$ or $\mathrm{FAA}\left(\mathrm{Q}^{2}=\right.$ 0.605 ) data set. Of the 2 -way combinations, those with SP had the strongest performances with the combined SP and IP data set being the best $\left(Q^{2}=0.929\right)$ of all. Adding FAA data to the SP and IP set did not improve the performance. The distribution of the sample scores on the first 2 principal component axes from PLSDA of combined SP and IP is shown in Figure 8.

Examination of the most important predictors for each model showed the prominent influence of SP in the discrimination among farms. The combined SP and IP model was dominated by soluble ( 4 of the first 5,7 of the first 10) and nonpolar peptides (5 of the first 5 , 8 of the first 10 and 14 of the first 20 VIP). When all 3 data sets were combined, the SP again dominated. Prominent SP for the farm discrimination were nonpolar based on their high retention times. This was also the case for the IP models, where again hydrophobic peptides had the highest VIP. The FAA model had strong influences from amino acids of dissimilar functionality (Tyr, Asp, Pro, Cys, Ile, and His). Tyrosine was in the top 5 VIP of all combined models and, with the exception of Asp in the FAA plus insoluble peptides model, the only amino acid in the first 20.

\section{CONCLUSIONS}

The application of chemometrics to the study of proteolytic profiles in Ragusano cheese was shown to be a powerful method to extract information from complex patterns of data. PDO Ragusano cheeses were differentiated by age and farm origin using exploratory data analysis (PCA and HCA) of peptide and FAA profiles. Partial least squares procedures also accomplished this and revealed that information in the SP and IP profiles was the most influential. A PLSR model for predicting cheese age was successfully constructed with the combi-

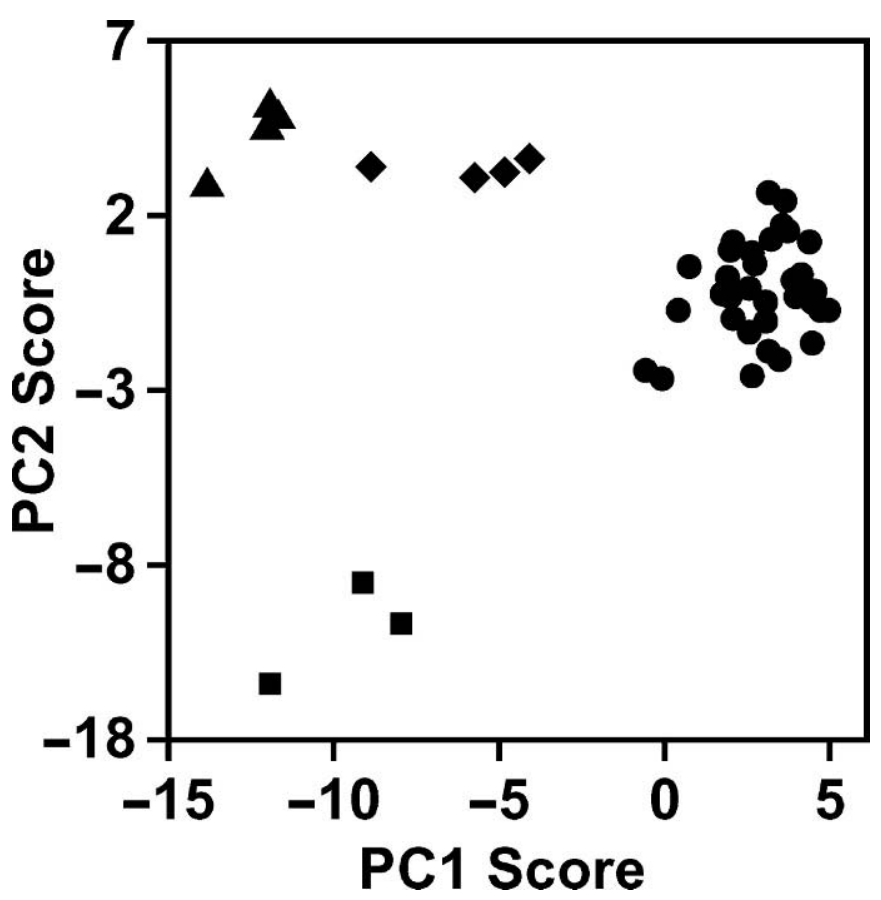

Figure 8. The distribution of the cheese samples classified according to farm ( farm 1; $\boldsymbol{\square}$ farm 2; $\boldsymbol{\Delta}$ farm 3; farm 4) by partial least squares discriminant analysis of combined $70 \%$ ethanol-soluble and -insoluble peptides. 
nation of peptide and FAA data, but the combined peptide data set without FAA was nearly as effective. The SP and IP profiles were also the most useful for classifying cheese samples according to their age and farm origin by PLSDA.

Analysis of cheese peptide data demonstrated that Ragusano cheese at 3 mo of age had clearly distinguishable peptide profiles from those at the other ages examined, which were essentially comparable. These findings related well with results from chemical analyses and confirmed our previous report (Fallico et al., 2003b). The early 4 mo of ripening are essential for producing the peptide profile typical of Ragusano cheese and less variation occurs between 4 to 7 mo of ripening. Chemometric analyses showed that the farm origin strongly affected cheese peptide profiles. Relatively nonpolar SP and, to a lesser extent, fairly nonpolar IP were found to be the most influential predictors in discriminating cheeses produced by different farms. Both results point to the factors characterizing the typical nature of Ragusano cheese. The traditional technology, providing for the use of raw milk and wooden cheese-making equipment, generates cheeses having unique features but also a great variability in cheese quality. This is linked to the contribution of native microflora from the local milk and environment to the cheese ripening, differing from farm to farm.

The extreme effects of the different contributions of farm-related native microflora to cheese ripening was reflected in the large variability observed in the FAA profile of Ragusano cheese. This probably prevented the establishment of a chemometric model, as has been successfully done by Resmini et al. (1985, 1993) for other traditional Italian cheeses. However, the same authors failed the application of a chemometric model to the FAA profile of Provolone cheese (Resmini et al., 1988), and similar problems were found by Innocente (1997) when attempting to evaluate the typical nature of Montasio cheese. The failure cases were probably due again to the typical nature of these cheeses, having peculiar qualitative and organoleptic features, but also a great variability in cheese quality (Fox et al., 1993). The effects of this variability are reflected on the biochemical events of cheese ripening, such as proteolysis, generating unpredictable profiles. In contrast, the uniformity in Parmigiano-Reggiano and Grana Padano cheese quality, guaranteed by the well-standardized technology, best fits to the chemometric modeling of compositional parameters. Further studies are needed to more deeply explore the relationships between variable microclimates, proteolysis, and development of typical characters of PDO Ragusano cheese.

\section{ACKNOWLEDGMENTS}

The authors thank John Hannon, Concetta Pediliggieri, Giovanna Farina, and Glenda Leto for technical assistance in cheese analysis. Financial support was provided by Assessorato Agricoltura e Foreste della Regione Siciliana, Palermo, Italy.

\section{REFERENCES}

Albenzio, M., M. R. Corbo, S. U. Rehman, P. F. Fox, M. De Angelis, A. Corsetti, A. Sevi, and M. Gobbetti. 2001. Microbiological and biochemical characteristics of Canestrato Pugliese cheese made from raw milk, pasteurized milk or by heating the curd in hot whey. Int. J. Food Microbiol. 67:35-48.

Andrews, A. T. 1983. Proteinases in normal bovine milk and their action on the caseins. J. Dairy Res. 50:45-55.

Association of Official Analytical Chemists. 2000. Official Methods of Analysis. 17th ed. AOAC, Gaithersburg, MD.

Barker, M., and W. Rayens. 2003. Partial least squares for discrimination. J. Chemom. 17:166-173.

Battistotti, B., and C. Corradini. 1993. Italian cheese. Page 221 in Cheese: Chemistry, Physics and Microbiology. Vol. 2. P. F. Fox, ed. Chapman and Hall, London, United Kingdom.

Beebe, K. R., R. J. Pell, and M. B. Seascholtz. 1998. Chemometrics: A Practical Guide. John Wiley \& Sons, Inc., New York, NY.

Blakesley, R. W., and J. A. Boezi. 1977. A new staining technique for proteins in polyacrylamide gels using Coomassie Brilliant Blue G250. Anal. Biochem. 82:580-581.

Bütikofer , U., and D. Fuchs. 1997. Development of free amino acids in Appenzeller, Emmentaler, Gruyere, Raclette, Sbrinz and Tilsiter cheese. Lait 77:91-100.

Bynum, D. G., and D. M. Barbano. 1985. Whole milk reverse osmose retentates for Cheddar cheese manufacture: Chemical changes during aging. J. Dairy Sci. 68:1-10.

Corsetti, A., M. R. Corbo, M. Albenzio, R. Di Cagno, M. Gobbetti, and P. F. Fox. 2001. Microbiology and biochemistry of Caciocavallo Silano cheese. Ital. J. Food Sci. 13:297-309.

Creamer, L. K. 1985. Water absorption by renneted casein micelles. Milchwissenschaft 40:589-591.

Fallico, V., L. Chianese, J. Horne, S. Carpino, and G. Licitra. 2003b. Influence of feeding strategy (pasture vs TMR) on proteolysis in Ragusano cheese during ripening. J. Dairy Sci. 86(Suppl. 1):367. (Abstr.)

Fallico, V., L. Chianese, S. Carpino, and G. Licitra. 2003a. Aspetti qualitativi equantitativi della proteolisi nel corso della stagionatura del formaggio Ragusano. Sci. Tecn. Latt.-Cas. 54:117-141.

Fenelon, M. A., P. O'Connor, and T. P. Guinee. 2000. The effect of fat content on the microbiology and proteolysis in Cheddar cheese during ripening. J. Dairy Sci. 83:2173-2183.

Fox, P. F., and B. F. Walley 1971. Influence of sodium chloride on the proteolysis of casein by rennet and by pepsin. J. Dairy Res. 38:165-170.

Fox, P. F., and T. P. Guinee. 1987. Italian cheeses. Pages 221-255 in Cheese: Chemistry, Physics and Microbiology. Vol. 2. P. F. Fox, ed. Elsevier Applied Sci., London, United Kingdom.

Fox, P. F., J. Law, P. L. H. McSweeney, and J. Wallace. 1993. Biochemistry of cheese ripening. Pages 389-438 in Cheese: Chemistry, Physics and Microbiology. Vol. 1. P. F. Fox, ed. Chapman and Hall, London, United Kingdom.

Gazzetta Ufficiale Comunità Europea. 1996. No. 1263. July 1, 1996. Gazzetta Ufficiale Repubblica Italiana. 1995. No. 133. June 9, 1995.

Gobbetti, M., S. Lowney, E. Smacchi, B. Battistotti, P. Damiani, and P. F. Fox. 1997. Microbiology and biochemistry of Taleggio cheese during ripening. Int. Dairy J. 7:509-517.

Grappin, R., and E. Beuvier. 1997. Possible implications of milk pasteurization on the manufacture and sensory quality of ripened cheese. Int. Dairy J. 7:751-761. 
Guinee, T. P., and P. F. Fox. 1984. Studies on Romano-type cheese: General proteolysis. Ir. J. Food Sci. Technol. 8:105-114.

Innocente, N. 1997. Free amino acids and water-soluble nitrogen as ripening indices in Montasio cheese. Lait 77:359-369.

International Dairy Federation. 1993. Standard Method 20B: Milk. Determination of nitrogen content. IDF, Brussels, Belgium.

International Dairy Federation. 1997. Standard Method 152A: Milk and milk products. Determination of fat content (general guidance on the use of butyrometric methods). IDF, Brussels, Belgium.

Kelly, M., P. F. Fox, and P. L. H. McSweeney. 1996. Effect of saltin-moisture on proteolysis in Cheddar-type cheese. Milchwissenschaft 51:498-501.

Krause, I., A. Bockhardt, and H. Klostermeyer. 1997. Characterization of cheese ripening by free amino acids and biogenic amines and influence of bactofugation and heat treatment of milk. Lait 77:101-108.

Kristiansen, K. R., A. S. Deding, D. F. Jensen, Y. Ardö, and K. B. Qvist. 1999. Influence of salt content on ripening of semi-hard round-eyed cheese of Danbo-type. Milchwissenschaft 54:19-23.

Kuchroo, C. N., and P. F. Fox. 1982. Soluble nitrogen in Cheddar cheese: Comparison of extraction procedures. Milchwissenschaft 37:331-335.

Lee, H. J., N. F. Olson, and D. B. Lund. 1980. Diffusion of salt, fatty acids and esterases in Mozzarella cheese. J. Dairy Sci. 63:513518.

Licitra, G., G. Portelli, P. Campo, G. Longombardo, G. Farina, S. Carpino, and D. M. Barbano. 1998. Technology to produce Ragusano cheese: A survey. J. Dairy Sci. 81:3343-3349.

Licitra, G., P. Campo, M. Manenti, G. Portelli, S. Scuderi, S. Carpino, and D. M. Barbano. 2000. Composition of Ragusano cheese during aging. J. Dairy Sci. 83:404-411.

Lynch, C. M., P. L. H. McSweeney, P. F. Fox, T. M. Cogan, and F. B. Drinan. 1996. Manufacture of Cheddar cheese with and without adjunct lactobacilli under controlled microbiological conditions. Int. Dairy J. 6:851-867.

McSweeney, P. L. H., and P. F. Fox. 1993. Cheese: Methods of chemical analysis. Pages 341-388 in Cheese: Chemistry, Physics, and Microbiology. Vol. 1: General Aspects. 2nd ed. P. F. Fox, ed. Chapman and Hall, London, United Kingdom.

McSweeney, P. L. H., N. F. Olson, P. F. Fox, A. Healy, and P. Hojrup. 1993. Proteolytic specificity of chymosin on bovine $\alpha_{\mathrm{s} 1}$-casein. J. Dairy Res. 60:401-412.
Melilli, C., D. M. Barbano, M. Manenti, J. M. Lynch, S. Carpino, and G. Licitra. 2004. Lipolysis and proteolysis in Ragusano cheese during brine salting at different temperatures. J. Dairy Sci. 87:2359-2374.

Mulvihill, D. M., and P. F. Fox. 1979. Proteolytic specificity of chymosin on bovine $\alpha_{\mathrm{s} 1}$-casein. J. Dairy Res. 46:641-651.

Noël, Y., Y. Ardo, S. Pochet, A. Hunter, P. Lavanchy, W. Luginbühl, D. Le Bars, A. Polychroniadou, and L. Pellegrino. 1998. Characterisation of protected denomination of origin cheeses: Relationships between sensory texture and instrumental data. Lait 78:569-588.

Polo, C., M. Ramo, and R. Sanchez. 1985. Free amino acids by high performance liquid chromatography and peptide by gel elctrophoresis in Mahòn cheese during ripening. Food Chem. 16:85-96.

Pripp, A. H., S. Leszek, and T. Sorhaug. 2000. Chemometrical analysis of proteolytic profiles during cheese ripening. Int. Dairy J. 10:249-253.

Resmini, P., J. A. Hogenboom, C. Pazzaglia, and L. Pellegrino. 1993. Gli amminoacidi liberi nella caratterizzazione analitica del formaggio Grana Padano. Sci. Tecn. Latt.-Cas. 1:7-19.

Resmini, P., L. Pellegrino, C. Pazzaglia, and J. A. Hogenboom. 1985. Gli amminoacidi liberi nella tipizzazione del formaggio Parmigiano Reggiano, ed in particolare nel prodotto grattuggiato. Sci. Tecn. Latt.-Cas. 36:557-592.

Resmini, P., L. Pellegrino, J. A. Hogenboom, and M. Bertuccioli. 1988. Indagine sulla composizione in amminoacidi liberi del formaggio Provolone quale possible elemento caratterizzante. Sci. Tecn. Latt.-Cas. 39:81.

Sousa, M. J., Y. Ardö, and P. L. H. McSweeney. 2001. Advances in the study of proteolysis during cheese ripening. Int. Dairy J. 11:327-345.

Urbach, G. 1990. Effect of feed on flavor in dairy foods. J. Dairy Sci. 73:3639-3650.

Visser, S. 1993. Proteolytic enzymes and their relation to cheese ripening and flavour: An overview. J. Dairy Sci. 76:329-350.

Wold, S. 1978. Cross-validatory estimation of the number of components in factor and principal components models. Technometrics 20:397-405.

Wold, S., A. Ruhe, H. Wold, and I. W. J. Dunn. 1984. The collinearity problem in linear regression: The partial least squares approach to generalized inverses. SIAM J. Sci. Statist. Comput. 5:735-743.

Wold, S., M. Sjöström, and L. Eriksson. 2001. PLS-regression: A basic tool of chemometrics. Chemom. Intell. Lab. Syst. 58:109-130. 